Using Innovation Configuration Mapping for the Implementation of Engineering Infused Science Lessons (research to practice)

Dr. Julia M. Ross, University of Maryland, Baltimore County

Dr. Jenny Daugherty, Purdue University, West Lafayette

Assistant Professor in the Department of Technology Leadership \& Innovation at Purdue University

Dr. Rodney L Custer, Black Hills State University

Dr. Custer is Provost and V.P. for Academic Affairs at Black Hills State University. He is PI on Project Infuse, a NSF funded project to research an engineering concept-based approach to professional development in life and physical science at the secondary level. 


\title{
Using Innovation Configuration Mapping for the Implementation of Engineering Infused Science Lessons (Research-to-Practice)
}

\author{
Addressing the NGSS: Supporting K-12 Teachers in Engineering Pedagogy and \\ Engineering-Science Connections
}

This paper describes the process for developing and using an innovation configuration (IC) map to guide the efforts of a National Science Foundation teacher professional development research project ${ }^{1}$, Project Infuse. The project was funded to study science teacher learning using an engineering-concept driven professional development program. This is particularly timely with the recent publication of the Next Generation Science Standards (NGSS) ${ }^{1}$ and the inclusion of an engineering dimension in science. The project research team has been investigating how to infuse engineering concepts into science given the time, resource, and curricular constraints of school environments. Specific implementation issues have been identified as important as teachers incorporate engineering infused lessons into their instruction. One key issue is that teachers new to engineering are often not clear on what they are being asked to do. Therefore, it is critical to create a common understanding of what engineering infusion actually looks like in the classroom. The IC Map is the tool chosen by the research team to create common understanding. This paper describes the process used by the team in developing and testing an IC Map for the implementation of engineering infused lessons in science classrooms. The current version of the IC map and the intended uses for the professional development program are included.

IC maps are a component of the Concerns-Based Adoption Model (CBAM). The developers of the CBAM recognized that the concerns of individuals going through change, such as an educational innovation, are very similar. ${ }^{2}$ CBAM outlines the kinds of questions and concerns related to the change that people are considering and experiencing. Early questions focus more on how the change will impact the individual and once these questions are resolved, questions emerge that are more task-oriented. As these are largely resolved, the individual can focus on impact. For teachers, these questions are about how the change will impact students. The CBAM includes ways to assess individuals across seven stages of concern (awareness, informational, personal, management, consequence, collaboration, refocusing). According to Loucks-Horsley, these stages are particularly important for teachers during professional development. ${ }^{3}$ They enable professional developers to understand where teachers are and address their questions and concerns throughout the professional development process. Acknowledging and addressing concerns is critical to successful reform efforts.

The diagnostic dimensions of the CBAM include: (a) the Stages of Concern measure, (b) the Levels of Use measure, and (c) the IC Map. The Stages of Concern measure identifies the intensity of the feelings the individual adopting the innovation is experiencing. The Levels of Use examines how the individual is using or adopting the innovation. IC maps are a tool used to understand implementation of an innovation at the individual level; to understand how the innovation looks when implemented by teachers and students. ${ }^{4}$ An IC map is a word-picture

\footnotetext{
${ }^{1}$ This material is based on work supported by the National Science Foundation under Grant No. 1158615.
} 
description of what the innovation looks like in practice; outlining what the individuals are doing when the innovation is implemented. It indicates the degree to which close adherence to the developer's intended model is advocated (i.e., fidelity) by presenting carefully developed descriptions of different ways of doing the innovation, including a number of components and variations. The major goal is to be as descriptive and visual as possible in creating word pictures that describe the various configurations possible with the innovation. The process is designed to provide the teachers with a clear vision of what infusing engineering concepts into their instruction looks like while they are engaged in the professional development program.

\section{Participants}

The teachers that participated in the pilot phase of the professional development were primarily science teachers with some previous engagement with engineering. They were selected so as to help inform the development of the professional development approach and activities, including the IC map. Limited numbers of technology and engineering teachers were also recruited for participation during the pilot phase of the project in order to examine the possible positive impact of these teachers on the professional development model. The physical science institute had 11 teachers (10 physical science and 1 technology \& engineering education) while the life science institute had 10 teachers (7 life science and 3 technology \& engineering education). Pilot teachers participated in two summer institutes, as well as professional development during the school year. Each summer institute was two weeks in length. A set of activities were developed and tested in a preliminary attempt to develop an effective professional development engineering infusion model that can be assessed and replicated. These activities were designed to correspond with the existing STEM professional development literature and deliver on the research questions. These activities are described in another 2014 ASEE conference paper, however the focus of this paper is to more fully describe the development of the project's IC map.

\section{Process for Developing the IC Map}

The process for developing IC maps outlined by Hall and Hord involves: (a) reviewing all printed materials related to the innovation; (b) observing a range of classrooms where the innovation is in use; (c) generating a list of possible components that represent the major parts of the innovation; (d) clustering suggestions that are similar and creating one statement to represent each set of the suggestions; (e) agreeing on which components are key and should be developed; (f) developing the wording of components (5-10) and component variations (A to E); and (g) testing the draft map for a "dose of reality" to identify points that need clarification and other components that need to be mapped. ${ }^{5}$

The process used to develop the IC map followed the steps listed above and built upon the experience of the project team in working with high school teachers to integrate engineering concepts into their classrooms. The leadership team began by generating and clustering a list of major components or conceptual themes that we thought best represented the engineering infusion innovation (based on standards documents, related literature and our own prior experiences with curriculum and professional development). This process involved numerous discussions and a series of iterations and yielded three major organizational themes. These are: 


\section{A. Curriculum Materials}

The curriculum materials chosen by the teacher should include engineering concepts, an open-ended design challenge, and be designed to facilitate the connection between engineering concepts and science learning. Materials should be standards-based and include a student assessment component.

\section{B. Teacher Practices: Design-Centered}

Design challenges should be structured as an open-ended team-based activity where each team is expected to generate a unique solution. When implementing the challenge, the teacher should take on the role of consultant/guide and support student teams in the use of a rational design process. In order to support science learning, the teacher should make explicit connections to science concepts when supporting design teams and routinely ask students to provide science-based rationale for design decisions.

\section{Teacher Practices: Design-Centered: Engagement with Engineering Concepts} Teachers should make explicit connections to engineering concepts throughout the lesson/unit and routinely use appropriate engineering terminology. Teachers should explicitly connect science concepts with real-world engineering applications and describe these applications as rationale for the learning of science.

The next step involved identifying a set of sub-components for the major categories. The Curriculum Materials theme consists of sub-components focused on such things as alignment of content with engineering concepts articulated in science standards, inclusion of well crafted, open-ended design challenges, and designed to enhance student engagement with science concepts. The Teacher Practices themes include sub-components focused on items such as quality of group-based activities, encouragement of students to engage in thoughtful preplanning, the generation of multiple solutions, and active reflection on engineering design practices. As was the case with identifying the major categories, the leadership team engaged in numerous conversations and the sub-categories have gone through multiple iterations.

Next, we developed descriptions of what implementation would look like across a spectrum of implementation alternatives. These descriptions represent the operational forms that have been observed as engineering infusion is implemented in the classroom. Different ways of doing engineering infusion were captured as levels for each sub-component within the IC map. Four levels were used for each sub-component to describe a range from more to less desirable implementation. Collectively, this process yielded a set of word-picture descriptions structured within a well-developed conceptual implementation framework. It should be noted that one key point of deliberation during the development process had to do with whether the focus should be (a) on teachers and their observable behaviors, (b) on students and their behaviors, or (c) a combination of the two. Given that the focus of the project is on teacher professional development, the decision was made to place the focus on teachers' understandings and actions. This decision is consistent with the advice by Hall and Hord to create maps for a single unique role group in order to provide the clearest and most straightforward depictions. ${ }^{6}$ However, during the initial stages of use and given the active learning nature of engineering design, we have 
discovered that a clean distinction between teacher and student understanding and behavior is difficult to maintain. Thus, the discussion of the shape of the map is ongoing.

We engaged the teachers during the second summer institute with the map as part of their professional development. The goals were to use the map as a communication and conceptualization tool and to leverage the teachers' experience in real world science classrooms to the map refinement process. The IC map was also used to select clips from video-taped lessons conducted by the teachers during the school year for use during the second summer's institutes. Selected video clips were woven together into a video using the IC map as a structure. These were used during the institutes to reinforce and explore understandings of engineering infusion.

During the 2013 summer institute, teacher feedback was collected on the structure and wording of the IC map through observation and interview protocols by the project evaluation team. The evaluation team then provided a "Revisions Document" from each PD site to the project team. The IC map was then revised and refined to incorporate teacher, evaluator, and professional development provider feedback. Therefore, all constituencies were engaged in the refinement process. The revised IC map is presented in the section below.

\section{The Project's Innovation Configuration (IC) Map}

\section{A. Curriculum Materials}

The curriculum materials chosen by the teacher should include engineering concepts, an open-ended design challenge, and be designed to facilitate the connection between engineering concepts and science learning. Materials should be standards-based and include a student assessment component.

If the curriculum chosen does not include engineering concepts, please check here and move on to B.

\begin{tabular}{|l|l|l|l|}
\hline \multicolumn{1}{|c|}{ a } & \multicolumn{1}{c|}{ b } & \multicolumn{1}{c|}{ c } & \multicolumn{1}{c|}{ d } \\
\hline $\begin{array}{l}\text { A1. Curriculum targets } \\
\text { engineering concepts } \\
\text { articulated in science } \\
\text { standards appropriate } \\
\text { to the course. }\end{array}$ & $\begin{array}{l}\text { Curriculum targets } \\
\text { engineering concepts } \\
\text { articulated in science } \\
\text { standards, but the concepts } \\
\text { targeted are not well- } \\
\text { matched to the course or } \\
\text { unit. }\end{array}$ & $\begin{array}{l}\text { Curriculum targets } \\
\text { engineering concepts, } \\
\text { but the concepts } \\
\text { targeted are not } \\
\text { standards-based. }\end{array}$ & $\begin{array}{l}\text { Curriculum does not } \\
\text { target science and } \\
\text { engineering standards. }\end{array}$ \\
\end{tabular}

\begin{tabular}{|l|l|l|l|}
\hline \multicolumn{1}{|c|}{ a } & \multicolumn{1}{c|}{ b } & \multicolumn{1}{c|}{ c } & \multicolumn{1}{c|}{$\mathrm{d}$} \\
\hline $\begin{array}{l}\text { A2. Materials chosen } \\
\text { include at least one } \\
\text { open-ended } \\
\text { engineering design } \\
\text { challenge that requires } \\
\text { understanding of } \\
\text { scientific concepts and } \\
\text { an iterative process for } \\
\text { optimal solutions. }\end{array}$ & $\begin{array}{l}\text { Materials include an } \\
\text { engineering design } \\
\text { challenge that requires } \\
\text { understanding of scientific } \\
\text { concepts for solutions, but } \\
\text { the scientific concepts are } \\
\text { not those targeted by the } \\
\text { teacher (unit, standards) }\end{array}$ & $\begin{array}{l}\text { Materials include an } \\
\text { engineering design } \\
\text { challenge that can be } \\
\text { solved simply by trial } \\
\text { and error without } \\
\text { understanding of } \\
\text { science concepts. }\end{array}$ & $\begin{array}{l}\text { Materials chosen } \\
\text { not include an open- } \\
\text { ended engineering } \\
\text { design challenge. }\end{array}$ \\
\end{tabular}




\begin{tabular}{|c|c|c|c|}
\hline $\begin{array}{l}\text { A3. Curriculum } \\
\text { materials make } \\
\text { explicit connections } \\
\text { between engineering } \\
\text { concepts and science } \\
\text { learning }\end{array}$ & $\begin{array}{l}\text { Curriculum materials } \\
\text { include engineering } \\
\text { concepts, but connection to } \\
\text { science learning is not } \\
\text { explicit. }\end{array}$ & $\begin{array}{l}\text { Curriculum materials } \\
\text { include engineering } \\
\text { concepts but present } \\
\text { them in total isolation } \\
\text { from science concepts. }\end{array}$ & $\begin{array}{l}\text { Curriculum materials } \\
\text { lack explicit } \\
\text { engineering concepts. }\end{array}$ \\
\hline
\end{tabular}

\begin{tabular}{|c|c|c|c|}
\hline a & $\mathrm{b}$ & c & $\mathrm{d}$ \\
\hline $\begin{array}{l}\text { A4. Materials include } \\
\text { a standards-based } \\
\text { student assessment } \\
\text { that explicitly targets } \\
\text { both science and } \\
\text { engineering concept } \\
\text { understanding in an } \\
\text { authentic context. }\end{array}$ & $\begin{array}{l}\text { Standards-based student } \\
\text { assessment is included and } \\
\text { targets engineering } \\
\text { concepts, but coverage of } \\
\text { engineering concepts is } \\
\text { minimal or exclusively at } \\
\text { the knowledge/ } \\
\text { comprehension level. }\end{array}$ & $\begin{array}{l}\text { Student assessment } \\
\text { includes engineering } \\
\text { concepts, but is not in } \\
\text { line with appropriate } \\
\text { standards. }\end{array}$ & $\begin{array}{l}\text { No evidence of student } \\
\text { learning assessment } \\
\text { that includes } \\
\text { engineering concepts. }\end{array}$ \\
\hline
\end{tabular}

\section{B. Teacher Practices: Design-Centered}

The design challenge should be structured as an open-ended team-based activity where each team is expected to generate a unique solution. When implementing the challenge, the teacher should take on the role of consultant/guide and support student teams in the use of a rational design process. In order to support science learning, the teacher should make explicit connections to science concepts when supporting design teams and routinely ask students to provide science-based rationale for design decisions.

If no engineering design challenge is used, please check here and move on to $\mathrm{C}$.

\begin{tabular}{|l|l|l|l|}
\hline \multicolumn{1}{|c|}{ a } & \multicolumn{1}{|c|}{ b } & \multicolumn{1}{c|}{ c } & \multicolumn{1}{c|}{ d } \\
\hline $\begin{array}{l}\text { B1. Teacher structures the } \\
\text { design challenge as a team- } \\
\text { based activity such that all } \\
\text { team members contribute to } \\
\text { the design solution. Checks } \\
\text { and balances are in place to }\end{array}$ & $\begin{array}{l}\text { Teacher structures the } \\
\text { design challenge as a } \\
\text { team-based activity, but } \\
\text { checks and balances are } \\
\text { not always effective to } \\
\text { ensure that all participate. }\end{array}$ & $\begin{array}{l}\text { Teacher structures the } \\
\text { design challenge as a } \\
\text { team-based activity, but } \\
\text { checks and balances are } \\
\text { not in place to ensure } \\
\text { participate. }\end{array}$ & $\begin{array}{l}\text { Design challenge is } \\
\text { structured as an } \\
\text { individual activity }\end{array}$ \\
\hline $\begin{array}{l}\text { Examples of "checks and balances" include the teacher actively asking about participation as he/she moves } \\
\text { participate. }\end{array}$ \\
from group to group, assigning individual students to play specific roles during the design challenge, including \\
a peer rating system in students' report-out and/or grade, and/or requiring each student to report out on results. \\
\hline
\end{tabular}

\begin{tabular}{|l|l|l|l|}
\hline \multicolumn{1}{|c|}{ a } & \multicolumn{1}{c|}{ b } & \multicolumn{1}{c|}{$\mathrm{c}$} & \multicolumn{1}{c|}{$\mathrm{d}$} \\
\hline $\begin{array}{l}\text { B2. Teacher encourages a } \\
\text { unique solution from each } \\
\text { team and actively supports } \\
\text { students in creating a unique } \\
\text { solution during the design } \\
\text { process. }\end{array}$ & $\begin{array}{l}\text { Teacher encourages a } \\
\text { unique solution from each } \\
\text { team in the activity's } \\
\text { introduction, but does not } \\
\text { actively support students } \\
\text { in creating a unique } \\
\text { solution during the design } \\
\text { process. }\end{array}$ & $\begin{array}{l}\text { Teacher does not } \\
\text { provide direction to } \\
\text { students regarding } \\
\text { "uniqueness" of design } \\
\text { solution. }\end{array}$ & $\begin{array}{l}\text { Teacher actively directs } \\
\text { students toward a single } \\
\text { solution. }\end{array}$ \\
\hline $\begin{array}{l}\text { Open ended design challenges have multiple solutions and in engineering it is desirable for a design to have } \\
\text { attributes that differentiate it from competitors. The word "unique" as used above is meant to capture this } \\
\text { element of engineering design. In the best case scenario, there would be some element or attribute to each } \\
\text { group's design that is a bit different from all the others. In other words, something that differentiates it and } \\
\text { makes it "unique". }\end{array}$ & \multicolumn{2}{|l|}{} \\
\hline
\end{tabular}




\begin{tabular}{|c|c|c|c|}
\hline$a$ & b & c & d \\
\hline $\begin{array}{l}\text { B3. Teacher actively checks } \\
\text { on group progress and } \\
\text { provides individual } \\
\text { coaching to groups by } \\
\text { making specific suggestions } \\
\text { for additional considerations } \\
\text { or next steps. }\end{array}$ & $\begin{array}{l}\text { Teacher actively checks } \\
\text { on group progress and } \\
\text { provides general coaching } \\
\text { to the class as a whole } \\
\text { rather than on an } \\
\text { individual group basis. }\end{array}$ & $\begin{array}{l}\text { Teacher observes group } \\
\text { work to check on } \\
\text { progress but does not } \\
\text { provide coaching at } \\
\text { either the class or } \\
\text { individual group level. }\end{array}$ & $\begin{array}{l}\text { Teacher neither checks } \\
\text { on group progress nor } \\
\text { offers coaching to } \\
\text { support group work. }\end{array}$ \\
\hline
\end{tabular}

\begin{tabular}{|l|l|l|l|}
\hline \multicolumn{1}{|c|}{ a } & \multicolumn{1}{c|}{ b } & \multicolumn{1}{c|}{ c } & \multicolumn{1}{c|}{ d } \\
\hline B4. Teacher requires & Teacher requires one & Teacher requires & No evidence of \\
students to engage in an & redesign. \\
iterative design process with & cycle redesign on paper & students to briefly \\
at least one opportunity for & testing or analysis of the & document what they & would do differently if \\
redesign, testing and & new design. & allowed to redesign. & \\
analysis. & & & \\
\hline
\end{tabular}

\section{Teacher Practices: Engagement with Engineering Concepts}

Teachers should make explicit connections to engineering concepts throughout the lesson/unit and routinely use appropriate engineering terminology. Teachers should explicitly connect science concepts with real-world engineering applications and describe these applications as rationale for the learning of science.

If no engineering concepts are included, please check here.

\begin{tabular}{|l|l|l|l|}
\hline \multicolumn{1}{|c|}{$\mathrm{a}$} & \multicolumn{1}{c|}{$\mathrm{b}$} & \multicolumn{1}{c|}{$\mathrm{c}$} & \multicolumn{1}{c|}{$\mathrm{d}$} \\
\hline $\begin{array}{l}\text { C1. Teacher makes explicit } \\
\text { connections to engineering } \\
\text { concepts throughout the } \\
\text { lesson/unit (i.e., in the lesson } \\
\text { introduction, primary } \\
\text { activity, and wrap up) }\end{array}$ & $\begin{array}{l}\text { Teacher makes explicit but } \\
\text { sporadic connections to } \\
\text { engineering concepts. }\end{array}$ & $\begin{array}{l}\text { Teacher makes implicit } \\
\text { connections to } \\
\text { engineering concepts. }\end{array}$ & $\begin{array}{l}\text { Teacher does not } \\
\text { make connections } \\
\text { to engineering } \\
\text { concepts. }\end{array}$ \\
\hline
\end{tabular}

\begin{tabular}{|l|l|l|l|}
\hline \multicolumn{1}{|c|}{ a } & \multicolumn{1}{c|}{ b } & \multicolumn{1}{c|}{ c } & \multicolumn{1}{c|}{ d } \\
\hline $\begin{array}{l}\text { C2. Teacher uses engineering } \\
\text { terminology correctly and } \\
\text { provides explicit instruction } \\
\text { on terminology to students. }\end{array}$ & $\begin{array}{l}\text { Teacher uses engineering } \\
\text { terminology correctly but } \\
\text { does not provide explicit } \\
\text { instruction to students. }\end{array}$ & $\begin{array}{l}\text { Teacher uses engineering } \\
\text { terminology but terms } \\
\text { are sometimes used } \\
\text { incorrectly. }\end{array}$ & $\begin{array}{l}\text { Teacher does not } \\
\text { use engineering } \\
\text { terminology. }\end{array}$ \\
\hline
\end{tabular}

\begin{tabular}{|l|l|l|l|}
\hline \multicolumn{1}{|c|}{ a } & \multicolumn{1}{c|}{ b } & \multicolumn{1}{c|}{ c } & \multicolumn{1}{c|}{ d } \\
\hline $\begin{array}{l}\text { C3. Teacher provides } \\
\text { rationale for science learning } \\
\text { throughout the lesson by } \\
\text { using real-world engineering } \\
\text { application(s) OR focusing } \\
\begin{array}{l}\text { on the science needed to } \\
\text { solve a real-world } \\
\text { engineering challenge. }\end{array}\end{array}$ & $\begin{array}{l}\text { Teacher provides rationale } \\
\text { for science learning using } \\
\text { real-world applications, but } \\
\text { significant "missed } \\
\text { opportunities" are evident. }\end{array}$ & $\begin{array}{l}\text { Teacher sometimes } \\
\text { mentions real-world } \\
\text { applications, but these } \\
\text { examples are not related } \\
\text { to the rationale for } \\
\text { science learning. }\end{array}$ & $\begin{array}{l}\text { Teacher does not } \\
\text { mention real-world } \\
\text { applications of } \\
\text { science concepts. }\end{array}$ \\
& & & \\
\hline
\end{tabular}

\begin{tabular}{|l|l|l|l|}
\hline \multicolumn{1}{|c|}{ a } & \multicolumn{1}{c|}{ b } & \multicolumn{1}{c|}{ c } & \multicolumn{1}{c|}{ d } \\
\hline $\begin{array}{l}\text { C4. Teacher routinely asks } \\
\text { students to provide scientific } \\
\text { and/or engineering rationale }\end{array}$ & $\begin{array}{l}\text { Teacher sporadically asks } \\
\text { students to provide } \\
\text { scientific and/or }\end{array}$ & $\begin{array}{l}\text { Teacher asks students to } \\
\text { provide scientific and/or } \\
\text { engineering rationale, }\end{array}$ & $\begin{array}{l}\text { Teacher does not } \\
\text { ask students to } \\
\text { provide scientific }\end{array}$ \\
\hline
\end{tabular}




\begin{tabular}{|l|l|l|l|}
\hline $\begin{array}{l}\text { for design decisions and } \\
\text { supports students in } \\
\text { developing detailed, correct } \\
\text { responses. }\end{array}$ & $\begin{array}{l}\text { engineering rationale and } \\
\text { supports students in } \\
\text { developing detailed, } \\
\text { correct responses. }\end{array}$ & $\begin{array}{l}\text { but accepts superficial or } \\
\text { incorrect responses. }\end{array}$ & $\begin{array}{l}\text { and/or engineering } \\
\text { rationale for design } \\
\text { decisions. }\end{array}$ \\
\hline
\end{tabular}

\section{Intended IC Map Uses and Challenges}

There are several intended uses for the IC map in the project. First and foremost, the map will be used as a professional development tool. Teacher interaction with the IC map and its components will provide a mechanism for clarifying what is meant by engineering infusion. The map will guide teachers in thinking about, discussing and assessing engineering infused curricula and personal teaching practices. The IC map also provides a framework for observing and discussing classroom videos throughout professional development. As such, the IC map will serve as a tool for teacher self-reflection and for coaching by professional development leaders. It will also provide a planning framework for science teachers to use as they begin infusing engineering content and activities into their courses/lessons.

On the project side, the IC map will be used as an interview tool, guiding the evaluation team as they probe teachers about their classroom activities including rationale for implementation choices. This use will allow the IC map to guide the planning of professional development activities and implementation supports. Within the project, the IC map developed will not be used as an observation protocol for research, teacher evaluation, or implementation assessment. However, these uses for IC maps have been documented ${ }^{7}$ and may be possible in the future depending on the specific goals of a given project.

One significant challenge in using the IC map is the fact that engineering infusion may encompass a single lesson, a set of lessons, or even a several week-long engineering challenge. As a result, not every dimension described above is likely to be applicable to a given lesson. From day to day, some dimensions will be more relevant than others. The goal of the map is to provide a word picture of what various aspects of engineering infusion look like in the classroom with the understanding that the map in its entirety would likely only apply to an extended set of lessons or project. Therefore, it is important that the IC map in its entirety not be used to evaluate a snapshot in time (i.e. a single lesson in isolation) to rate a lesson or teacher as "strong" or "weak." Rather, its primary purpose is to provide a framework for teachers to create a common understanding of engineering infusion. This fact is difficult for teachers new to engineering infusion, because it requires a certain level of expertise to judge which aspects of the map are appropriate to a given lesson. Instruction pertaining to the IC map and its intended uses is necessary during professional development before teachers are comfortable with the tool.

\section{Summary and Conclusions}

The IC map development process has been of particular value to the project in two primary ways over the past year. First, it has provided the leadership team with a mechanism for clearly thinking through what, in our best collective judgment, engineering-infused life and physical science instruction and best practices look like. The second value has been in engaging teachers with the draft IC map as part of the professional development process. Specifically, we believe there is significant professional development value in involving the teachers in a process of reviewing and improving the IC mapping tool. Including the teachers in the process of refining the map has allowed them to better visualize how engineering concepts can most effectively be 
infused into their science classes. Involving the teachers has also provided the leadership team with valuable "reality checking" on our vision of implementation.

Despite the value IC maps bring to the project, feedback from evaluator interviews and observation protocols suggest that high school teachers are uncomfortable with its use. There has been an overwhelming call for the map to be refocused on the student rather than on the teacher or for a mixed model. In some cases, this is a result of teachers wanting to focus on the students exclusively rather than on themselves. In other cases, it is difficult to express map dimensions solely in terms of the teachers. Regardless, in order for the IC map to be an effective professional development tool, it will need to be introduced to the teachers in clear detail early and often in the professional development experience and trainers who provide the professional development will need to be very clear as to the intended purposes of map.

\section{References}

1. NGSS Lead States. 2013. Next Generation Science Standards: For States, By States. Washington, DC: The National Academies Press

2. Hall, G.E., \& Hord, S.M. (1987). Change in schools: Facilitating the process. New York: State University of New York Press.

3. Loucks-Horsley, S. (1996). "The Concerns-Based Adoption Model (CBAM): A model for change.” Retrieved from http://www.nas.edu/rise/backg4a.htm. From Loucks-Horsley, S. "Professional development for science education: A critical and immediate challenge" in National standards \& the science curriculum, edited by Rodger Bybee, Dubuque, Iowa: Kendall/Hunt Publishing Co.

4. Hall, G.E., \& Hord, S.M. (2011). Implementing change: Patterns, principles, and potholes, $3^{\text {rd }}$ ed. Boston: Pearson.

5. Hall \& Hord (2011).

6 . Hall \& Hord (2011).

7. Hall \& Hord (2011). 